\title{
PENGARUH CORPORATE SOCIAL RESPONSIBILITY INDEKS TERHADAP KINERJA PERUSAHAAN (STUDY PADA PERUSAHAAN INFRASTRUKTUR, UTILITAS, DAN TRANSPORTASI YANG LISTING DI BURSA EFEK INDONESIA)
}

\author{
Ika Mar'atus Sholihah \\ Elva Nuraina \\ Pendidikan Akuntansi IKIP PGRI MADIUN \\ Putrychacha13@yahoo.com
}

\begin{abstract}
This study aims to determine the effect of corporate social responsibility on firm performance. In this study, the company's financial performance is measured by using ROA (Return on Assets). The sample used in this study were all enterprise infrastructure, utilities, and transportation are listed on the Indonesia Stock Exchange and publish the annual report in 2010-2012 on the website by using the method of purposive www.idx.co.id judgemen. The method of analysis used in the multiple regression study. Based on the test results, it was found that corporate social responsibility (CSR) has positive effect on firm performance. While the significance test results are known corporate social responsibility partially index does not affect the performance of the company, only leverage control variables are significantly influence the performance of the company.
\end{abstract}

Keywords: Corporate Social Responsibility, Leverage, Size, ROA

\begin{abstract}
ABSTRAK
Penelitian ini bertujuan untuk mengetahui pengaruh corporate social responsibility indeks terhadap kinerja perusahaan. Dalam penelitian ini, kinerja keuangan perusahaan diukur dengan menggunakan ROA (Return On Asset). Sampel yang digunakan dalam penelitian ini adalah semua perusahaan infrastruktur, utilitas, dan transportasi yang listing di Bursa Efek Indonesia dan menerbitkan annual report pada tahun 2010-2012 di website www.idx.co.id dengan menggunakan metode purposive judgemen. Metode analisis yang digunakan pada penelitian regresi berganda. Berdasarkan hasil pengujian, ditemukan bahwa variabel corporate social responsibility (CSR) berpengaruh positif terhadap kinerja perusahaan. Sementara hasil uji signifikasi diketahui corporate social responsibility indeks secara parsial tidak berpengaruh terhadap kinerja perusahaan, hanya variabel kontrol leverage saja yang berpengaruh secara signifikan terhadap kinerja perusahaan.
\end{abstract}

Kata Kunci : Corporate Social Responsibility, Leverage, Size, ROA

\section{PENDAHULUAN}

Pengukuran kinerja merupakan suatu tolok ukur bagi manajemen perusahaan dalam menentukan kebijakan perusahaan, apakah kinerja perusahaan sudah baik dari segi keuangan maupun nonkeuangan (Iman Widodo, 2011: 10). Hal tersebut menjadikan pengukuran kinerja perusahaan menjadi hal yang sangat 
penting bagi manajemen untuk melakukan evaluasi terhadap performa perusahaan dan perencanaan tujuan di masa mendatang. Berbagai informasi dihimpun agar pekerjaan yang dilakukan dapat dikendalikan dan dipertanggungjawabkan untuk mencapai efisiensi dan efektivitas pada seluruh proses bisnis perusahaan. Gambaran mengenai kinerja perusahaan bisa di dapatkan dari dua sumber, yakni informasi finansial dan informasi nonfinansial. Informasi finansial didapatkan dari penyusunan anggaran untuk mengendalikan biaya. Sedangkan informasi nonfinansial merupakan faktor kunci untuk menetapkan strategi yang dipilih guna melaksanakan tujuan yang telah ditetapkan.

Peningkatan kinerja perusahaan strategi yang bisa ditempuh oleh perusahaan salah satunya adalah dengan menerapkan corporate social responsibility dalam pengembangannya yang merupakakan klaim stakeholders yang bertujuan supaya perusahaan tidak hanya memicu pada kepentingan para pemegang saham (shareholders) saja namun kemaslahatan pihak stakeholders dalam praktik bisnisnya yang meliputi para pekerja, komunitas, pemeritah, lembaga swadaya masyarakat, konsumen dan lingkungan sosial juga perlu diperhatikan. Oleh karena itu, suatu perusahaan tidak hanya beroperasi untuk kepentingan para pemegang saham (shareholders), tetapi juga untuk kepentingan pihak stakeholders dalam praktik bisnis. Kajian mengenai corporate social responsibility semakin berkembang pesat seiring banyak kasus yang terjadi dimana perusahaan tidak memberikan kontribusi positif secara langsung kepada masyarakat bahkan memberikan dampak negatif atas beroperasinya perusahaan (Danu Candra, 2011: 1).

Di Indonesia pemerintah telah mengeluarkan Undang-Undang Perseroan Terbatas No.40 Pasal 74 tahun 2007, mewajibkan perusahaan yang melakukan kegiatan usaha di bidang/berkaitan dengan sumber daya alam wajib melakukan tanggung jawab sosial dan lingkungan. Penyajian laporan tahunan diwajibkan juga untuk para perseroan agar melaporkan pelaksanaan CSR, sehingga semua stakeholders dapat mengetahui dan menilai efektivitas dari pelaksanaan kegiatan CSR tersebut. Penelitian ini mengambil perusahaan dari sektor infrastruktur, utilitas, dan transportasi yang terdaftar di Bursa Efek Indonesia (BEI). Sektor tersebut mempunyai beberapa sub sektor yaitu energi, telekomunikasi, transportasi dan kontribusi non bangunan. Perusahaan pada sektor tersebut berhubungan erat dengan penggunaan umum, jadi perusahaan sangat memperhatikan loyalitas konsumen, karyawan, lingkungan dan pihak-pihak yang berpengaruh pada perusahaan. Penerapan CSR pada perusahaan diharapkan dapat meningkatkan profitabilitas dan hubungannya dengan stakeholders, sehingga program corporate social responsibility berpengaruh positif dengan kinerja perusahaan.

\section{TELAAH LITERATUR}

\section{Corporate social responsibility}

Corporate social responsibility atau tanggung jawab sosial adalah jiwa perusahaan untuk mencapai tujuan-tujuan bisnis yang mencangkup citra perusahaan, promosi, meningkatkan penjualan, membangun percaya diri, loyalitas karyawan, serta keuntungan, dalam konteks lingkungan eksternal, tanggung jawab sosial berperan dalam memenuhi kebutuhan masyarakat seperti kesempatan kerja dan stabilitas sosial-ekonomi-budaya (Poerwanto, 2010: 21). Tanggung jawab 
sosial secara lebih sederhana dapat dikatakan sebagai timbal balik perusahaan kepada masyarakat dan lingkungan sekitarnya karena perusahaan telah mengambil keuntungan atas masyarakat dan lingkungan sekitarnya. Proses pengambilan keuntungan tersebut perusahaan seringkali menimbulkan kerusakan lingkungan dan dampak sosial lainnya (Danu Candra, 2011: 16).

Darwin dalam Rahmawati (2012: 182) mendefinisikan tanggung jawab sosial perusahaan atau corporate social responsibility adalah mekanisme bagi suatu organisasi untuk secara sukarela mengintregrasikan perhatian terhadap lingkungan dan sosial ke dalam operasinya dan interaksinya dengan stakeholders, yang melebihi tanggung jawab organisasi di bidang hukum. Pendapat tersebut sejalan dengan penjelasan Stephen (2010: 127) bahwa tanggung jawab sosial telah disebut "hanya menghasilkan keuntungan", melakukan lebih dari menghasilkan keuntungan," aktivitas perusahaan tambahan yang dimaksud untuk meningkatkan kesejahteraan sosial atau lingkungan", sehingga tanggung jawab sosial perusahaan dapat dipahami sebagai kebijakan-kebijakan dan tindakan-tindakan perusahaan dalam berinteraksi dengan lingkungannya yang didasarkan pada etika. Tindakan dan kebijakan perusahaan merupakan keluaran organisasi yang menjadi motor dalam perjalanan mencapai tujuan-tujuan yang telah ditetapkan.

\section{Kinerja Perusahaan}

Danu Candra (2011: 21) mendefinisikan kinerja perusahaan merupakan sesuatu yang dihasilkan oleh suatu perusahaan dalam periode tertentu dengan mengacu pada standar yang telah ditetapkan sebelumnya. Hendaknya kinerja perusahaan merupakan hasil yang dapat diukur dan menggambarkan kondisi empirik suatu perusahaan dari berbagai ukuran yang disepakati, sedangkan Iman Widodo (2011: 10) mengungkapkan kinerja adalah suatu tampilan keadaan secara utuh atas perusahaan selama periode waktu tertentu, merupakan hasil atau prestasi yang dipengaruhi oleh kegiatan operasional perusahaan dalam memanfaatkan sumber daya- sumber daya yang dimiliki.

Moeheriono (2010: 61) berdasarkan definisi tersebut, maka terdapat beberapa aspek yang mendasar dan paling pokok dari pengukuran kinerja, yaitu sebagai berikut:

1. Menetapkan tujuan, sasaran dan strategi organisasi, denagn menetapkan secara umum apa yang diinginkan oleh organisasi sesuai dengan tujuan, visi dan misinya.

2. Merumuskan indikator kinerja dan ukuran kinerja, yang mengacu pada penilaian kinerja secara tidak langsung, sedangkan indikator kinerja mengacu pada pengukuran kinerja secara langsung yang berbentuk keberhasilan utama (critical success factors) dan indikator kinerja kunci (key performance indicator).

3. Mengukur tingkat capaian tujuan dan sasaran organisasi, menganalisis hasil pengukuran kinerja yang dapat diimplementasikan dengan membandingkan tingkat capaian tujuan dan sasaran organisasi.

4. Mengevaluasi kinerja dengan menilai kemajuan organisasi dan pengambilan keputusan yang berkualitas, memberikan gambaran atau hasil kepada organisasi seberapa besar tingkat keberhasilan tersebut dan mengevaluasi langkah apa yang diambil organisasi selanjutnya. 
Oleh karena itu, hendaknya kinerja perusahaan merupakan hasil yang bisa diukur sehingga dapat memberikan gambaran dan hasil sesuai dengan ukuran yang disepakati, untuk mengetahui kinerja perusahaan maka perlu penilaian kinerja. Tujuan dari penilaian kinerja adalah untuk memotivasi para karyawan dalam mencapai sasaran organisasi dan dalam mematuhi standar prilaku yang telah ditetapkan sebelumnya agar membuahkan hasil dan tindakan yang diinginkan. Standar perilaku tersebut berupa kebijakan manajemen atau rencana formal yang dituangkan dalam anggaran perusahaan. Penilaian kinerja juga digunakan untuk menekan perilaku yang tidak semestinya melalui reward yang diberikan oleh perusahaan dan hasil kinerja (Danu Candra, 2011: 21).

\section{ROA Sebagai Pengukur Kinerja Keuangan Perusahaan}

Return on Assets (ROA) merupakan salah satu rasio untuk mengukur profitabilitas perusahaan, yaitu merupakan perbandingan antara laba bersih sesudah pajak dengan total aset (Reni Hariyani, 2011: 44).

Keseluruhan ukuran untuk (profitability) adalah return on asset, maka dengan mengetahui rasio ini, dapat dinilai apakah perusahaan telah efisien dalam memanfaatkan asetnya dan kegiatan operasional perusahaan. Rasio ini juga memberikan ukuran yang lebih baik atas profitabilitas perusahaan, karena menunjukkan efektivitas manajemen dalam menggunakan aset untuk memperoleh pendapatan sehingga dapat meningkatkan kinerja perusahaan (Reni Hariyani, 2011: 47).

\section{KERANGKA BERPIKIR DAN PENGEMBANGAN HIPOTESIS Gambar 1 Kerangka Berpikir}

\begin{tabular}{|c|c|}
\hline $\begin{array}{l}\text { Variabel Independen }(\mathbf{X}) \\
\text { Corporate Social Responsibility } \\
\quad \text { - Ekonomi }\end{array}$ & $\begin{array}{l}\text { Variabel Dependen }(\mathbf{Y}) \\
\text { Kinerja Perusahaan } \\
\text { - ROA }\end{array}$ \\
\hline $\begin{array}{l}\text { - Tenaga Kerja } \\
\text { - Hak Asasi Manusia } \\
\text { - Sosial } \\
\text { - Produk/Jasa }\end{array}$ & \begin{tabular}{l}
\multicolumn{1}{c}{ T } \\
Variabel Kontrol \\
- Size \\
- Leverage
\end{tabular} \\
\hline
\end{tabular}

Berdasarkan skema kerangka berpikir diatas, terdapat dua variabel, yaitu variabel bebas (independent) $\mathrm{X}$ berupa corporate social responsibility sedangkan variabel terikat (dependent)Y berupa kinerja perusahaan dengan variabel kontrol size dan leverage. Penelitian ini bertujuan untuk mengetahui pengaruh corporate social responsibility indeks terhadap kinerja perusahaan infrastruktur, utilitas dan transportasi yang listing di BEI.

\section{Hipotesis Penelitian}

$\mathbf{H}_{0}=$ Tidak ada pengaruh positif corporate social responsibility indeks terhadap 
kinerja perusahaan (Infrastruktur, Utilitas dan Transportasi) yang listing di Bursa Efek Indonesia.

$\mathbf{H}_{1}=$ Ada pengaruh positif corporate social responsibility indeks terhadap

kinerja perusahaan (Infrastruktur, Utilitas dan Transportasi) yang listing di Bursa Efek Indonesia.

\section{METODOLOGI PENELITIAN}

\section{Jenis dan Sumber Data}

Data yang digunakan dalam penelitian ini adalah data sekunder.

\section{Populasi, Sampel, dan Teknik Pengambilan Sampel}

1. Populasi Populasi dalam penelitian ini adalah semua perusahaan pada sektor Infrastruktur, Utilitas dan Transportasi yang keseluruhannya berjumlah 48 perusahaan.

2. Sampel

Tabel 1

Kriteria-kriteria Sampel

\begin{tabular}{|l|l|l|}
\hline No & Kriteria-kriteria & Jumlah \\
\hline 1 & $\begin{array}{l}\text { Perusahaan merupakan perusahaan infrastruktur, } \\
\text { utilitas dan transportasi yang terdiri dari beberapa } \\
\text { sub sektor meliputi: }\end{array}$ & - Seb sektor energi. \\
- Sub sektor telekomunikasi & 48 \\
\hline 2 & $\begin{array}{l}\text { Perusahaan tersebut berturut-turut menerbitkan } \\
\text { laporan keuangan dan pengungkapan corporate } \\
\text { social responsibility ditahun 2010-2012 }\end{array}$ & 20 \\
\hline 3 & $\begin{array}{l}\text { Berdasarkan kriteria, total sampel dalam periode } \\
\text { penelitian selama 3 tahun }\end{array}$ & 60 \\
\hline
\end{tabular}

3. Teknik Pengambilan Sampel

Teknik pengambilan sampel dalam penelitian ini adalah dengan purposivel judgemental sampling, yaitu penarikan sampel berdasarkan pertimbangan tertentu bentuk sampel non-probabilitas yang didasarkan kriteria-kriteria tertentu (Asep Hermawan, 2005: 155).

\section{Instrumen Penelitian}

Instrumen pada penelitian ini seperti yang digunakan dalam standar Global Reporting Initiative meliputi ekonomi, lingkungan, tenaga kerja, sosial, hak asasi manusia dan produk sebagai dasar sustainability reporting. GRI di dalamnya meliputi beberapa indikator mulai dari kinerja ekonomi, lingkungan, 
tenaga kerja, hak asasi manusia, produk dan sosial yang diperoleh dari website www.globalreporting.co.id

\section{ANALISIS DATA}

1. Statistik Deskriptif

Statistik Deskriptif digunakan untuk melihat informasi pengungkapan corporate social responsibility yang ada di Indonesia dan terdaftar dalam Bursa Efek Indonesia (BEI), dan pengaruhnya secara simultan dan parsial terhadap kinerja perusahaan tersebut.

2. Analisis Regresi

Model regresi yang digunakan untuk menguji hipotesis yaitu:

$$
\mathrm{Y}=\mathrm{CSR}+\text { Size }+ \text { Leverage }+\varepsilon
$$

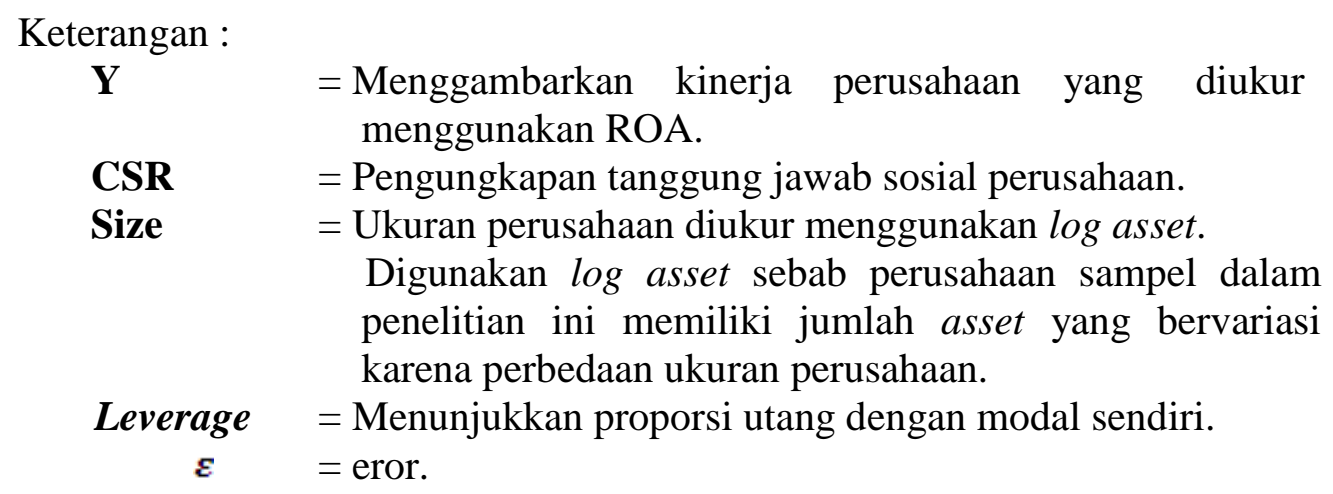

3. Uji Normalitas

Uji normalitas dilakukan untuk mengetahui apakah nilai residu (perbedaan yang ada) yang diteliti memiliki distribusi normal atau tidak normal.

4. Uji Asumsi Klasik

Uji Asumsi Klasik berguna untuk menguji bahwa model regresi linier merupakan model yang baik.

a. Uji Heterokedastisitas

Uji Heterokedastisitas bertujuan untuk menguji apakah dalam model regresi terjadi ketidaksamaan varian dari residual satu pengamatan ke pengamatan lain tetap, maka disebut homokedastisitas, dan jika berbeda disebut heterokedastisitas. Cara untuk mendeteksi ada atau tidaknya heteroskedastisitas adalah dengan menggunakan uji Park Gleyser. Jika hasil nilai probabilitasnya memiliki nilai signifikasi > nilai alphha-nya (0.05), maka model tidak mengalami heteroskedastisitas (Agung, 2012: 93).

\section{b. Uji Multikolonieritas}

Uji Multikolonieritas bertujuan untuk menguji apakah model regresi ditemukan adanya korelasi antar variabel bebas (independen). Gejala multikolinearitas dapat diketahui melalui tool uji yang disebut Variance Inflation Factor (VIF), jika nilai VIF kurang dari 10, itu 
menunjukan model tidak terdapat gejala multikolinearitas, artinya tidak terdapat hubungan antara variabel bebas (Agung, 2012: 87).

c. Uji Autokorelasi

Uji ini bertujuan untuk melihat ada atau tidaknya korelasi antara residual pada suatu pengamatan dengan pengamatan yang lain pada model. Cara untuk mendeteksi ada tidaknya autokorelasi dapat diketahui dengan menilai tingkat probabilitas, jika $>0.05$ berarti tidak terjadi autokorelasi dan sebaliknya (Agung, 2012: 102).

5. Pengujian Hipotesis

a. Koefisien Determinasi $\left(\mathrm{R}^{2}\right)$

Analisis ini digunakan dalam hubungannya untuk mengetahui jumlah atau persentase sumbangan pengaruh variabel bebas dalam model regresi yang secara serentak atau bersama-sama memberikan pengaruh terhadap variabel tidak bebas, jadi koefisien angka yang ditunjukan memperlihatkan sejauh mana model yang terbentuk dapat menjelaskan kondisi yang sebenarnya. Agung (2012: 136) memberikan rumus mencari Koefisien Determinasi (KD) secara umum sebagai berikut:

$$
\mathrm{R}^{2}=\frac{\text { Sum of } \text { Squares } \text { Regression }}{\text { Sum of Squares } \text { Total }}
$$

b. Uji Signifikansi Simultan (Uji Statistik F)

Tahap-tahap untuk menentukan uji $\mathrm{F}$ adalah sebagai berikut:

1) Merumuskan hipotesis

$\mathrm{Ho}=$ Corporate social responsibility indeks tidak berpengaruh positif terhadap kinerja perusahaan (Infrastruktur, Utilitas dan Transportasi).

$\mathrm{Ha}=$ Corporate social responsibility indeks berpengaruh positif terhadap kinerja perusahaan (Infrastruktur, Utilitas dan Transportasi).

2) Menentukan tingkat signifikasi

Jika signifikan $>0,05$ maka Ho diterima.

Jika signifikan $<0,05$ maka Ho ditolak.

3) Kriteria pengujian

Ho diterima bila $\mathrm{F}$ hitung $<\mathrm{F}$ tabel.

Ho ditolak bila $\mathrm{F}$ hitung $>\mathrm{F}$ tabel.

c. Uji Signifikan Parameter Individual (Uji Statistik t)

Adapun langkah-langkah untuk uji t adalah:

1) Merumuskan hipotesis

Ho $=$ Corporate social responsibility indeks secara parsial tidak berpengaruh terhadap kinerja perusahaan (Infrastruktur, Utilitas, dan Transportasi).

$\mathrm{Ha}=$ Corporate social responsibility indeks secara parsial berpengaruh terhadap kinerja perusahaan (Infrastruktur, Utilitas, dan Transportasi). 
2) Menentukan tingkat signifikan Jika signifikan $>0,05$ maka Ho diterima. Jika signifikan $<0,05$ maka Ho ditolak.

3) Kriteria pengujian

Ho diterima jika : $\mathrm{t}$ hitung $<\mathrm{t}$ tabel

Ho ditolak jika : $t$ hitung $>\mathrm{t}$ tabel

\section{PEMBAHASAN}

\section{Pengujian Data}

a. Uji Normalitas

Uji Kolmogorov-Smirnov

Kurva nilai residual terstandarisasi sebagaimana diuraikan di atas dikatakan normal jika nilai Kolmogorov-Smirnov : Z $<$ Ztabel ; atau menggunakan nilai probability Sig (2 tailed) > a ; sig > 0,05 (Agung, 2012: $61)$.

Tabel 2

One-Sample Kolmogorov-Smirnov Test

\begin{tabular}{|l|c|}
\hline & Unstandardized Residual \\
\hline $\mathrm{N}$ & 40 \\
\hline Kolmogorov-Smirnov Z & 1,257 \\
\hline Asymp. Sig. (2-tailed) & 0,085 \\
\hline
\end{tabular}

Sumber : Hasil Olah Data SPSS

Berdasarkan data pada tabel 2 di atas diketahui bahwa nilai probability Sig ( 2 tailed) sebesar $0,085>\mathrm{a}=0,05$ dengan demikian dapat dinyatakan bahwa data yang digunakan dalam penelitian ini terdistribusi secara normal.

b. Uji Asumsi Klasik

1) Uji Heterokedastisitas

Untuk mengetahui adanya heteroskedastisitas dalam penelitian ini dilakukan dengan grafik scatterplot sebagai berikut :

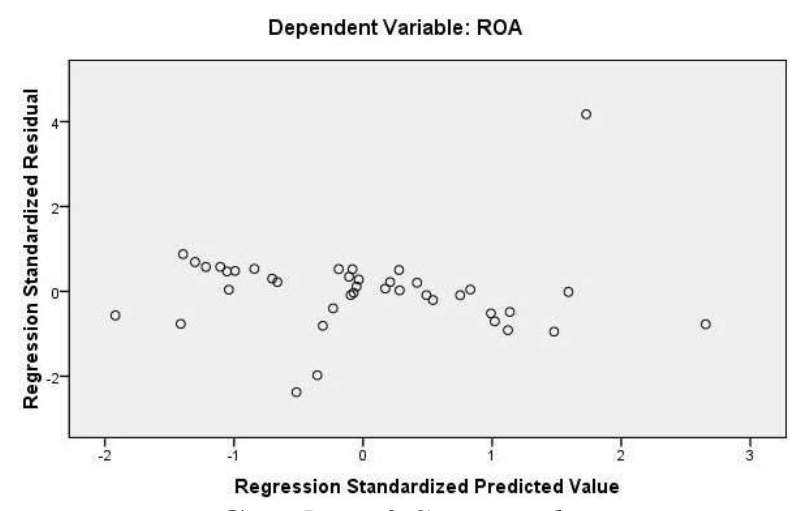

Gambar 4 Scatterplot

Sumber : Hasil Olah Data SPSS

Gambar scatterplot di atas menunjukkan hubungan antara Regression Studentised Residual dengan Regression Standardized 
Predicted Value. Pada grafik scatterplot ditunjukkan bahwa titiktitik yang digambarkan pada grafik tersebut menyebar dan tidak membentuk pola tertentu, dengan demikian model regresi diindikasikan tidak terdapat masalah heteroskedastisitas yang berarti pada model tersebut varian residual dari satu pengamatan ke pengamatan yang lain adalah tetap, atau homoskedastisitas.

Uji heteroskedastisitas selain menggunakan grafik scatterplot diperlukan uji Park Gleyser untuk memperkuat hasil pengujian secara grafis. Hasil perhitungan menggunakan uji Park Gleyser .

Tabel 3

\section{Hasil Uji Park Gleyser}

\begin{tabular}{|l|r|r|r|r|r|}
\hline \multirow{3}{*}{ Model } & \multicolumn{2}{|c|}{$\begin{array}{c}\text { Unstandardized } \\
\text { Coefficients }\end{array}$} & $\begin{array}{c}\text { Standardized } \\
\text { Coefficients }\end{array}$ & \multirow{2}{*}{$\mathrm{t}$} & \multirow{2}{*}{ Sig. } \\
\cline { 2 - 5 } & \multicolumn{1}{c|}{$\mathrm{B}$} & Std. Error & \multicolumn{1}{|c|}{ Beta } & & \\
\hline (Constant) & 0,475 & 0,181 & & 2,618 & 0,013 \\
\hline LEVERAGE & $-0,006$ & 0,024 & $-0,044$ & $-0,264$ & 0,794 \\
\hline SIZE & $-0,021$ & 0,011 & $-0,309$ & $-1,938$ & 0,061 \\
\hline CSR & $-0,046$ & 0,082 & $-0,094$ & $-0,561$ & 0,578 \\
\hline
\end{tabular}

Sumber : Hasil Olah Data SPSS

Berdasarkan data pada tabel 3 di atas, diketahui bahwa nilai tstatistik dari seluruh variabel penjelas tidak ditemukan adanya nilai yang signifikan secara statistik karena bernilai di atas 0,05, sehingga dapat disimpulkan bahwa model ini tidak mengalami masalah heteroskedastisitas.

2) Uji Multikolonieritas.

Tabel 4

Nilai VIF dan Tolerance

\begin{tabular}{|l|c|c|}
\hline \multirow{2}{*}{\multicolumn{1}{|c|}{ Model }} & \multicolumn{2}{c|}{ Collinearity Statistics } \\
\cline { 2 - 3 } & Tolerance & VIF \\
\hline LEVERAGE & 0,876 & 1,141 \\
\hline SIZE & 0,972 & 1,029 \\
\hline CSR & 0,880 & 1,136 \\
\hline
\end{tabular}

Sumber : Hasil Olah Data SPSS

Berdasarkan tabel 4 diatas diketahui bahwa semua nilai VIF dari masing-masing variabel bebas dibawah 10 sementara itu nilai tolerance yang diperoleh mendekati 1, dengan demikian dapat disimpulkan bahwa tidak terdapat masalah multikolonieritas dari model regresi dalam penelitian ini 
3) Uji Autokorelasi

Untuk mengetahui adanya autokorelasi dalam penelitian ini dilakukan dengan pengujian nilai Durbin-Watson menggunakan bantuan program SPSS dan diperoleh hasil seperti pada tabel 5.

Tabel 5

Uji Durbin - Watson

\begin{tabular}{|c|c|c|c|}
\hline Model & $\begin{array}{c}\text { Durbin- } \\
\text { Watson }\end{array}$ & Kriteria & \multicolumn{1}{|c|}{ Keterangan } \\
\hline 1 & 2,088 & $\mathrm{du}<\mathrm{d}<4-\mathrm{du}$ & $\begin{array}{l}\text { tidak ada autokorelasi } \\
\text { positif dan negatif }\end{array}$ \\
\hline
\end{tabular}

Sumber : Hasil Olah Data SPSS

Berdasarkan data pada tabel 5 di atas diketahui bahwa nilai DurbinWatson yang diperoleh dalam pengujian ini adalah sebesar 2,088, untuk mengetahui hasil uji Durbin Watson ini sudah memenuhi pengujian autokorelasi maka diperlukan nilai dL dan Du pada tabel statistik d (Durbin-Watson). Berdasarkan tabel statistik d pada tingkat signifikansi $0,05, \mathrm{k}=3$ dan $\mathrm{n}=40$, diperoleh nilai $\mathrm{d}_{\mathrm{L}}=$ 1,3384 dan $\mathrm{d}_{\mathrm{U}}=1,6589$, dengan demikian nilai $4-\mathrm{d}_{\mathrm{L}}=2,6616$ dan nilai $4-\mathrm{d}_{\mathrm{U}}=2,3411$, untuk lebih jelasnya dapat dilihat pada gambar berikut :

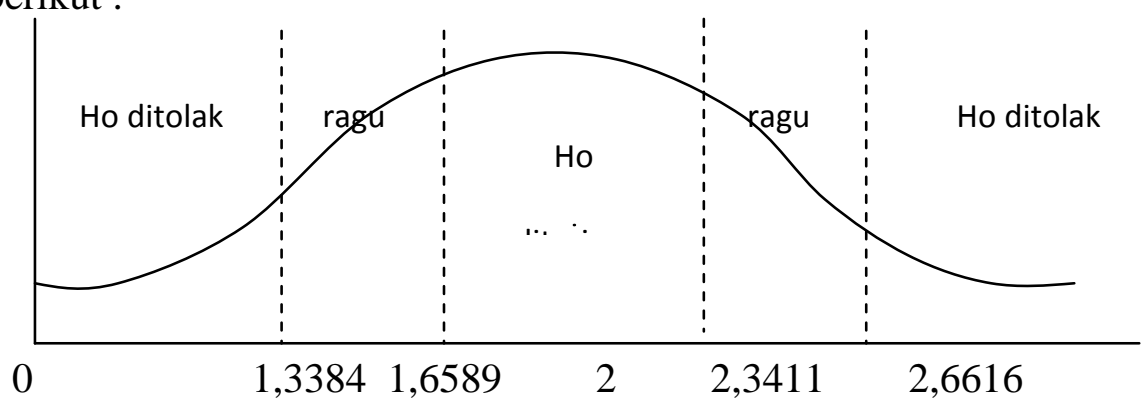

Gambar 4 Grafik Durbin-Watson

Bila du $<\mathrm{d}<4$-du maka Ho tidak di tolak, menunjukkan tidak ada autokorelasi positif dan negatif. Nilai $\mathrm{d}=2,088$ berada diantara du $=$ 1,6589 dan 4-du = 2,3411, hal ini menunjukkan tidak ada autokorelasi positif dan negatif. Sehingga disimpulkan bahwa pada persamaan tidak terjadi masalah autokorelasi.

\section{Analisis Statistik}

a. Koefisien Determinasi $\left(\mathrm{R}^{2}\right)$

Tabel 6

Perhitungan Koefisien Determinasi

\begin{tabular}{|c|c|c|c|}
\hline Model & R & R Square & Adjusted $R$ Square \\
\hline 1 & 0,551 & 0,304 & 0,246 \\
\hline
\end{tabular}

Sumber : Hasil Olah Data SPSS

Data pada tabel 6 di atas menunjukkan bahwa nilai koefisien korelasi dalam penelitian ini adalah sebesar 0,551. Artinya hubungan antara CSR, leverage dan size secara bersama-sama terhadap ROA adalah dengan 
tingkat keeratan sebesar 0,551. Hal ini menunjukkan hubungan antar variabel yang terjadi adalah sedang karena angkanya berada antara $0,40-$ 0,599, sedangkan nilai koefisien determinasi $\left(\mathrm{R}^{2}\right)$ adalah sebesar 0,304. Hal ini menunjukkan bahwa variabel kinerja perusahaan (ROA) dapat dijelaskan oleh variabel corporate social responsibility (CSR), leverage dan size secara bersama-sama sebesar $30,4 \%$. Sedangkan sisanya sebesar $69,6 \%$ dipengaruhi oleh faktor lain yang tidak menjadi pokok bahasan pada penelitian ini.

b. Uji Signifikansi Simultan (Uji Statistik F)

Tabel 7

Hasil Uji Simultan

\begin{tabular}{|l|c|c|c|c|c|}
\hline \multicolumn{1}{|c|}{ Model } & $\begin{array}{c}\text { Sum of } \\
\text { Squares }\end{array}$ & Df & $\begin{array}{c}\text { Mean } \\
\text { Square }\end{array}$ & F & Sig. \\
\hline Regression & 0,454 & 3 & 0,151 & 5,234 & 0,004 \\
\hline Residual & 1,041 & 36 & 0,029 & & \\
\hline Total & 1,495 & 39 & & & \\
\hline
\end{tabular}

Sumber : Hasil Olah Data SPSS

Berdasarkan tabel 7 di atas, maka dapat diketahui nilai $F_{\text {hitung }}$ adalah sebesar 5,234 pada taraf signifikasi 0,004. Nilai $F_{\text {hitung }}$ ini akan dibandingkan dengan nilai $\mathrm{F}_{\text {tabel }}$, sedangkan untuk menentukan nilai $\mathrm{F}_{\text {tabel }}$ dilakukan dengan cara sebagai berikut :

Ftabel $F_{\alpha} ; K-1: N-K ; \mathrm{F}_{0,05} ; 4-1: 40-4=2,87$

dimana $\alpha=$ derajat signifikansi.

$\mathrm{N}$ = jumlah sampel/observasi (40).

$\mathrm{K}=$ banyaknya parameter (4).

Berdasarkan hasil perhitungan di atas dapat diketahui bahwa nilai $F_{\text {hitung }}=$ $5,234>\mathrm{F}_{\text {tabel }}=2,87$. Hal ini berarti hipotesis nol diterima dan hipotesis kerja ditolak, dengan demikian variabel corporate social responsibility (CSR), leverage dan size secara bersama-sama berpengaruh terhadap variabel kinerja perusahaan (ROA).

c. Uji Signifikan Parameter Individual (Uji Statistik t)

Tabel 8

Hasil Uji Signifikan

\begin{tabular}{|c|c|c|c|c|c|}
\hline \multirow[t]{2}{*}{ Model } & \multicolumn{2}{|c|}{$\begin{array}{c}\text { Unstandardized } \\
\text { Coefficients }\end{array}$} & \multirow{2}{*}{$\begin{array}{c}\text { Standardized } \\
\text { Coefficients } \\
\text { Beta } \\
\end{array}$} & \multirow[t]{2}{*}{$\mathrm{t}$} & \multirow[t]{2}{*}{ Sig. } \\
\hline & $\mathrm{B}$ & Std. Error & & & \\
\hline (Constant) & 0,416 & 0,245 & & 1,698 & 0,098 \\
\hline LEVERAGE & $-0,123$ & 0,033 & $-0,556$ & $-3,742$ & 0,001 \\
\hline SIZE & $-0,027$ & 0,015 & $-0,258$ & $\mid-1,827$ & 0,076 \\
\hline CSR & 0,144 & 0,110 & 0,193 & 1,303 & 0,201 \\
\hline
\end{tabular}

Sumber : Hasil Olah Data SPSS 
Berdasarkan data pada tabel 8 di atas, maka persamaan regresi linier berganda dalam penelitian ini adalah sebagai berikut :

$$
\mathrm{Y}_{\mathrm{t}+1}=0,416+0,144 \mathrm{CSR}-0,123 \text { leverage }-0,027 \text { size }+\mathrm{e}
$$

Interprestasi dari persamaan di atas adalah sebagai berikut :

1. $\mathrm{a}=0,060$, berarti tanpa adanya variabel independent yaitu corporate social responsibility (CSR), leverage dan size, maka besarnya kontribusi variabel kinerja perusahaan adalah sebesar - 0,416.

2. $\mathrm{b}_{1}=0,144$, berarti apabila variabel CSR ditingkatkan sebesar 1 persen, maka akan berpengaruh terhadap peningkatan kinerja perusahaan (ROA) sebesar 0,144 atau $14,4 \%$ dan menganggap variabel lain yaitu leverage dan size adalah konstan.

3. $\mathrm{b}_{2}=-0,123$, berarti apabila variabel leverage ditingkatkan sebesar 1 persen, maka akan berpengaruh terhadap penurunan kinerja perusahaan (ROA) sebesar 0,123 atau 12,3\% dan menganggap variabel lain yaitu CSR dan size adalah konstan.

4. $b_{3}=-0,027$, berarti apabila variabel size ditingkatkan sebesar 1 persen, maka akan berpengaruh terhadap penurunan kinerja perusahaan (ROA) sebesar 0,027 atau $2,7 \%$ dan menganggap variabel lain yaitu CSR dan leverage adalah konstan.

Tabel 8 di atas juga menunjukkan bahwa dari tiga variabel bebas dalam penelitian ini hanya variabel leverage yang berpengaruh signifikan terhadap variabel kinerja perusahaan. Sedangkan nilai signifikasi variabel CSR sebesar 0,201 dan variabel size sebesar 0,076 nilainya lebih besar dari 0,05. Sehingga dapat dinyatakan bahwa variabel CSR dan size dalam penelitian ini tidak berpengaruh signifikan terhadap variabel kinerja perusahaan.

\section{KESIMPULAN}

Berdasarkan hasil analisis data dan pembahasan yang dilakukan, maka kesimpulan yang didapat dalam penelitian ini adalah sebagai berikut :

1. Koefisien regresi variabel corporate social responsibility (CSR) adalah bernilai positif, dengan demikian corporate social responsibility indeks secara simultan berpengaruh positif terhadap kinerja perusahaan (Infrastruktur, Utilitas dan Transportasi). Disebabkan karena dengan penerapan corporate social responsibility dapat memberikan dampak yang baik pada stakeholder sehingga berpengaruh pada kinerja perusahaan.

2. Hasil uji signifikasi diketahui corporate social responsibility indeks secara parsial tidak berpengaruh secara signifikan terhadap kinerja perusahaan (Infrastruktur, Utilitas, dan Transportasi). Hal tersebut disebabkan karena minimnya perusahaan yang mengungkapkan corporate social responsibility yang sesuai dengan indikator yang telah ditetapkan oleh GRI yang digunakan sebagai dasar penghitungan CSR pada penelitian ini, sehingga nilai antara perhitungan tertinggi dan terendah dari pengungkapan CSR terpaut sangat jauh menyebabkan CSR tidak memberi pengaruh secara signifikan terhadap kinerja perusahaan. 


\section{Saran}

Berdasarkan hasil analisa data dan kesimpulan yang diperoleh, maka saran yang dapat dikemukakan dalam penelitian ini adalah :

1. Pengungkapan CSR oleh perusahaan memberi pengaruh positif meskipun tidak signifikan. Namun pengembangan perusahaan dengan tetap mempertimbangkan aspek-aspek lingkungan demi kepentingan stakeholder tentu akan lebih baik jika diperhatikan dan dilaksanakan.

2. Perusahaan sebaiknya mulai mengaplikasikan model pengukuran kinerja CSR yang terintegrasi dan dapat diukur agar dapat diketahui kinerja CSR secara baik dan dapat mendukung sistem pengukuran kinerja perusahaan.

3. Perlu dilakukan penelitian dengan sampel yang lebih banyak dan interval tahun yang lebih lama sehingga data yang dipaparkan dan dianalisa lebih akurat.

\section{DAFTAR PUSTAKA}

Agung Edy Wibowo. 2012. Aplikasi Praktis SPSS dalam Penelitian. Yogyakarta: Gava Media.

Asep Hermawan. 2005. Penelitian Bisnis Paradigma Kuantitatif. Jakarta: PT. Grasindo.

Budi Cahyono. 2011. Pengaruh Corporate Social Responsibility Terhadap Kinerja Perusahaan dengan Kepemilikan Asing Sebagai Variabel Moderating. Unpublished Skripsi. Semarang: Fakultas Ekonomi Universitas Diponegoro..

Danu Candra Indrawan. 2011. Pengaruh Corporate Social Responsibility Terhadap Kinerja Perusahaan. Unpublished Skripsi. Semarang: Fakultas Ekonomi Diponegoro.

Duwi Prianto. 2013. Mandiri Belajar Analisis Data Dengan SPSS. Yogyakarta: Mediakom

Faddly Akbar. 2012. Pengaruh Kinerja Keuangan dan Corporate Social Responsibility (CSR) terhadap nilai perusahaan pada perusahaan manufaktur yang terdaftar di BEI. Jurnal Akuntansi. Fakultas Ekonomi: Universitas Gunadarma.

Handayani Tri Wijayanti. 2011. Pengaruh Corporate Social Responsibility dan Manajemen Laba Terhadap Kinerja Keuangan dan Nilai Perusahaan. Jurnal Akuntansi dan Manajemen. Vol. 22: 67-70.

Irawan dan Basu Swastha. 1981. Lingkungan Perusahaan. Yogyakarta: BPFE UGM 
I Dewa Ketut. 2011. Pengaruh Corporate Social Responsibility Terhadap Kinerja Keuangan Perusahaan. Unpublished Skripsi. Semarang: Fakultas Ekonomi Universitas Diponegoro.

Iman Widodo. 2011. Analisis Kinerja Perusahaan dengan Menggunakan Pendekatan Balanced Scorecard (Studi Kasus Pada Perusahaan Mebel PT. Jansen Indonesia). Unpublished Skripsi. Semarang: Fakultas Ekonomi Universitas Diponegoro.

Krismiaji dan Aryani Anni. 2011. Akuntansi Manajemen. Yogyakarta: Sekolah Tinggi Ilmu Manajemen YKPN.

Lely Dahlia, Silvia Veronica. 2008. Pengaruh Corporate Social Responsibility Terhadap Kinerja Perusahaan (Studi Empiris pada Perusahaan yang Tercatat Di Bursa Efek Indonesia Tahun 2005 dan 2006). Jurnal Akuntansi. (1): 1-5 Diunduh 25 Februari 2013.

Marissa Yaparto. 2013. Pengaruh Corporate Social Responsibility Terhadap Kinerja Keuangan Pada Sektor Manufaktur Yang Terdaftar Di Bursa Efek Indonesia Pada Periode 2010-2011. Calyptra: Jurnal Ilmiah Mahasiswa Universitas Surabaya. Vol.2 No. 1

Mardiasmo. 2009. Akuntansi Sektor Publik. Yogyakarta: C.V ANDI OFFSET.

Moeheriono. 2009. Pengukuran Kinerja Berbasis Kompetensi. Bogor: Ghalia Indonesia

Mulyadi. 2001. Akuntansi Manajemen. Jakarta: Salemba Empat

Ni Wayan dan Made Gede. 2011. Pengaruh Kinerja Keuangan Terhadap Nilai Perusahaan denagan Pengungkapan Corporate Social Responsibility dan Good Corporate Governance sebagai Variabel Moderasi. Jurnal Akuntansi. Fakultas Ekonomi: Universitas Udayana.

Poerwanto. 2010. Corporate Social Responsibility. Yogyakarta: Pustaka Pelajar.

Rahmawati. 2012. Teori Akuntansi Keuangan. Yogyakarta: Graha Ilmu

Reni Hariyani. 2011. Pengaruh Implementasi Corporate Social Responsibility (CSR) terhadap perbedaan profitabilitas perusahaan (studi kasus PT Unilever Indonesia Tbk). Jurnal Akuntansi. Fakultas Ekonomi: Universitas Budi Luhur.

Reny dan Denies. 2012. Pengaruh Good Governance dan Pengungkapan Corporate Social Responsibility Terhadap Nilai Perusahaan (studi empiris pada perusahaan yang terdaftar di bursa efek Indonesia periode 2007-2010). Jurnal Nominal. Vol 1. No.1 
Rulfah M. Daud dan Abrar Amri. 2008. Pengaruh Intellectual Capital Dan Corporate Social Responsibility Terhadap Kinerja Perusahaan (Studi Empiris Pada Perusahaan Manufaktur Di Bursa Efek Indonesia). Jurnal Telaah \& Riset Akuntansi. Vol. 1, No.2 Hal. 213-231.

Stephen Robbins. 2010. Manajemen. Jakarta: Erlangga.

Sudaryanto. 2011. Pengaruh Kinerja Lingkungan terhadap Kinerja Finansial Perusahaan dengan Corporate Social Responsibility Disclosure sebagai Variabel Intervening. Unpublished Skripsi. Semarang: Fakultas Ekonomi Universitas Diponegoro.

Vesi, Gusnardi dan Riadi. 2012. Pengaruh Corporate Social Responsibility dan Good Corporate Governance Terhadap Kinerja Perusahaan (studi pada perusahaan manufaktur di BEI tahun 2009-2011). Jurnal Akuntansi. Pendidikan Ekonomi: Universitas Riau.

Wahyu Ardimas. 2011. Pengaruh kinerja keuangandan corporate social responsibility (CSR) terhadap nilai perusahaan pada Bank go public yang terdaftar di BEI. Jurnal Akuntansii. Fakultas Ekonomi: Universitas Gunadarma.

\section{Referensi Website :}

www.globalreporting.co.id di akses pada tanggal 02 Maret 2013.

www.idx.co.id di akses pada tanggal 05 Maret 2013 